\title{
A history of the marketing of British Columbia softwood lumber
}

\author{
by David H. Cohen ${ }^{1}$
}

\begin{abstract}
This paper provides a historical account of the marketing of British Columbia softwood lumber, one of Canada's pioneering lumber exporting regions. History teaches lessons concerning cooperation, the necessity for market diversity, and understanding customers' perspectives. As customer orientation becomes increasingly important for lumber producers to maintain and/or improve their international competitive position, foresters need to become more aware of the international marketing of wood products. Understanding the history of marketing B.C. lumber products can provide the foundation for foresters to help plan future exporting accomplishments.
\end{abstract}

Key words: lumber exporting, forest product marketing, forest history, British Columbia forest products
Cet exposé constitue un relevé historique de la mise en marché du bois de sciage de résineux provenant de la Colombie-Britannique, l'une des régions pionnières au Canada pour l'exportation du bois de sciage. L'histoire nous enseigne des leçons se rapportant à la coopération, à la nécessité de diversifier les marchés et à la compréhension du point de vue des consommateurs. À mesure que l'approche client devient de plus en plus importante pour les producteurs de bois de sciage qui tentent de maintenir ou encore d'améliorer leur position face à la compétition internationale, les forestiers doivent de plus en plus se familiariser avec la mise en marché des produits forestiers au niveau international. La compréhension de l'histoire de la mise en marché des produits du sciage de la C.-B. peut constituer la base permettant aux forestiers de pouvoir participer à la planification des prochaines réalisations dans le domaine des exportations.

Mots clés: exportation de bois de sciage, mise en marché des produits forestiers, histoire forestière, produits forestiers de la Colombie-Britannique.

\section{Introduction}

A strong customer-oriented marketing and promotional effort by the British Columbia forest products industry is a key component of the strategy necessary to maintain and/or enhance the global competitive position of this industry in future (Woodbridge, Reed \& Associates 1988). This strategy is being recommended not only for British Columbia, but by government and industry associations for the Canadian, New Zealand, Chilean, and United States forest products industries as well. Marketing efforts must be integrated linking the customer, through sales, back to both manufacturing and woodlands operations. However, prior to developing export policies to implement customer-oriented marketing to promote valueadded wood products, it would be beneficial to examine the history of marketing B.C. softwood lumber. Past marketing efforts have aided British Columbia in supplying over $30 \%$ of the value of world softwood lumber exports in 1987 (Forestry Canada 1990).

Lumber products from the vast $\mathrm{BC}$ forest resource have historically been substantially greater than the Canadian population could use. During the late 1980 s when Canada's population surpassed 25 million, domestic demand required less than $25 \%$ of production by volume (Council of Forest Industries of British Columbia (COFI) 1990). British Columbia had to develop export markets for its wood products for the industry to develop and grow. The need to focus on exports fostered the initiation of many of the marketing practices undertaken by producing regions today. Lessons can be learned from past successes and failures to aid lumber producing regions in planning for future accomplishments in the export of value-added wood products.

\footnotetext{
${ }^{1}$ Department of Wood Science, Faculty of Forestry, University of British Columbia, Vancouver, British Columbia, Canada V67 1 Z4.

Portions of this paper were published as Forest Economics and Policy Analysis Research Unit (FEPA) Working Paper \#152.
}

\section{The 19th Century}

Prior to the twentieth century, the B.C. forest industry concentrated on providing high-quality spars for sailing ships and timbers for mines and wharves - in modern marketing jargon this would be called "providing high-quality specialty products to targeted market niches". As early as 1863-4, solid wood products from British Columbia were being shipped to Australia, Hawaii, China, Peru, Chile, France and Spain (Taylor 1975). In 1871, Chile was the largest importer of BC wood and imported 10 cargo ships of lumber valued at $\$ 57,671$ while sales to the U.S. amounted to only $\$ 258$. While quantities were small, relative to modern-day shipments, one of the fundamental justifications for the formation of the BC wood products industry was to provide high value products for export markets. The first wave of sawmill expansion, during the 1880s, supplied the domestic market and the rapidly expanding Canadian rail lines with ties, bridge timbers and construction lumber.

\section{The Establishment of $\mathrm{BC}$ as a Key Player in World Markets: 1900-1920}

The second wave of sawmill expansion occurred in the early 1900s as U.S. business interests reacted to the creation of their National Park system by obtaining large tracts of timber rights in British Columbia (McKay 1982). In the early twentieth century, BC possessed timber resources, energy and mill sites for far more lumber production than the province, or even Canada, could use. It is during the twentieth century that the marketing of $\mathrm{BC}$ solid wood products evolved from infancy to become a well-respected and frequently imitated force in the global market for wood products.

The first cooperative promotional organization was formed in 1900 with a mandate that included the development of world markets for BC wood products: the BC Lumber and Shingle Manufacturers Association. In 1903, the organization divided into two product-oriented associations: one for shingles and one 
for lumber. The British Columbia Lumber Manufacturers Association (BCLMA) represented the producers of BC's most important solid wood product — lumber.

For the first 20 years of this century, the vast majority of BCs wood export business relied on U.S. broker houses situated predominantly in San Francisco, Portland and Seattle. British Columbia was considered the marginal producers and $\mathrm{BC}$ lumber was sold in the international markets only when U.S. firms either could not, or did not, want the business (McKay 1982). U.S. wood producers often preferred to supply rapidly expanding domestic markets rather than develop export markets. They only filled the most profitable offshore orders since U.S. supply and demand for lumber was relatively balanced. This left only erratic and unprofitable export orders for BC firms. The industry in British Columbia was sputtering; there was little consistency in production, employment, or profitability (McKay 1982).

In an effort to establish a consistent industry, the Federal government sent H.R. MacMillan, past Chief Forester of British Columbia, to the United Kingdom in 1915, as a one-man special trade commission. The objective of this first wood-oriented trade mission was to develop direct links for Canadian wood products in export markets and circumvent U.S. export firms. Initially, the trip was to cover all of Europe, but the First World War restricted the scope of coverage to the United Kingdom. MacMillan made many recommendations, several with a strong market and customer orientation, such as a proposal to establish an infrastructure for frequent and regular contact between producing mills of B.C. and their overseas customers in the United Kingdom (McKay 1982). The Federal government chose not to implement any of the recommendations and the increase in export orders resulting from MacMillan's trip was temporary. Government inaction opened the door for private entrepreneurship.

In 1919, H.R. MacMillan and M.L. Meyer formed H.R. MacMillan Export Company Limited, the first privatelyowned lumber brokerage firm based in British Columbia. Meyer had been a timber buyer for the U.K. government and was ideally positioned to supply the building boom in the U.K. after the First World War, while H.R. MacMillan had been an Assistant Manager of a BC lumber mill that had exported most of its production (McKay 1982). This was a marriage made for profit and foreshadowed many of the current joint ventures between companies from importing and exporting countries.

This partnership may have contributed to the placing of an order for over 70 million board feet of $\mathrm{BC}$ lumber by the British Timber Control Board. The size of this order was unprecedented in the history of the $\mathrm{BC}$ industry and required the output of every mill in the province. Unlike the industry structure in the United States, the BC lumber industry was composed of a multitude of small companies with no firm of the magnitude of the larger U.S. producers (McKay 1982). This single order instigated the formation of the Associated Timber Exporters of BC (Astexco) in 1919, a consortium of BC coastal mills that banded together as the best, and possibly only, way of filling this order (Perrault 1985). Unparalleled cooperation among the $\mathrm{BC}$ wood products industry enabled this order to be successfully filled and established British Columbia as a new and reliable source of large quantities of lumber. Cooperation among small producers enabled the industry to compete with much larger producers in both the United States and Europe.
In 1919, during negotiations for filling the order, Sir James Ball, the British Timber Controller, made several interesting comments while visiting British Columbia. He rebuked the $\mathrm{BC}$ forest industry for not actively seeking export orders and for the wasted timber that resulted from fires and harvesting policies (Perrault 1985). These criticisms could have been levelled at forest industries throughout North America. Seventy years laters, criticisms concerning waste and environmental concerns are re-emerging in the European marketplace, while Japan is rebuking U.S. producers for inactive pursuit of export orders (Lean 1991). Partly in response to Ball's criticism, the Forest Products Extension Bureau was established in 1922 to develop new markets and promote BC wood products worldwide (Perrault 1985).

\section{Rapid Production and Export Expansion: 1920-1930}

Throughout the twenties, Astexco filled orders Free Alongside Ship (FAS), that is, delivered to the shipyards, where MacMillan would purchase the lumber, load it onto his own ships, transport it to final markets, and complete the sale of lumber to brokers. With H.R. MacMillan handling the majority of export sales and shipping, and Astexco ensuring adequate production, the twenties witnessed ever-increasing lumber exports from British Columbia (MacKay 1982). In 1918, only 5\% of BC wood production was exported, but by 1929 exports had grown to over 27\% (BCLMA 1926-1930). During this time, the U.S. industry was primarily concerned with filling domestic orders since lumber demand surpassed supply resulting in an inactive export stance and increasing importation of BC lumber products.

From 1919 to 1923 , Britain was the largest importer of $\mathrm{BC}$ wood products, with H.R. MacMillan handling almost all of the shipping. Lumber exported by H.R. MacMillan was branded "HRM" for his company name; however, in Britain many customers assumed that this stood for "His Royal Majesty" and that the lumber was approved or recommended by royalty (MacKay 1982). To this day, this is one of the most successful brand naming strategies in the wood products industry.

The advantages of export market diversity were well stated by H.R. MacMillan in 1921 when he claimed that he served four distinct areas of the globe: China, Japan, the U.K. and Oceana (New Zealand and Australia); if one was weak, another was strong and profitability was assured (MacKay 1982). Sixty years later, the importance of diversified buyers to minimize purchaser power was one of the key components of Porter's seminal work on competitive strategy (Porter 1980).

Marketing efforts contributed to the British Columbia forest industry taking full advantage of an expanding world economy to firmly establish a consistent and growing lumber industry. In 1924, the Canadian government, with full cooperation of the $\mathrm{BC}$ industry, sent a major exhibit of Canadian wood and wood products to England for the Empire Exhibition (BCLMA 1926-30). This was one of the first recorded uses of demonstration homes to promote wood products, a technique much in use during the past two decades by both Canadian and U.S. associations. The demonstration house consisted of a tworoom bungalow built entirely of BC wood products. Despite much favourable press, solid public interest was not translated into sales because of poor follow-up by BC wood producers (BCLMA 1926-30). British Columbia producers abandoned much of the U.K. market and drastically reduced shipments as 
more profitable markets opened up in Japan and the northeastern United States. By the late nineteen-twenties, Japan had become BC's largest overseas market, while the U.S. was importing almost twice as much wood as was being shipped overseas by the province (Perrault 1985).

Much of the competition during this era was not from other lumber producing regions in the globe but from substitute products such as steel, concrete and brick. The importance of educating people about western North American wood species and the proper use of wood cannot be overstated. The powerful engine for growth that an expanding world economy and an effective marketing program creates is well illustrated by the growth in $\mathrm{BC}$ 's lumber industry during the twenties. Unfortunately, too many markets increased wood use due to educated populations and then were abandoned by the BC industry for more lucrative markets elsewhere (MacKay 1982). This pattern has been repeated to this day. For example, in the seventies the BC industry abandoned the N.E. United States for the more lucrative California market. During the recession of the eighties, when the industry tried to re-capture lost market share in the N.E. United States, they found customers had permanently switched to lumber from the more readily available S.E. United States. All the market share and price premiums that had been abandoned could not be re-captured.

Mill owners felt that MacMillan was not passing on a fair proportion of the profits to their mills, reflecting the ever-present conflict between supplier and wholesaler. With particularly bad timing, Astexco formed Seaboard Lumber Sales Limited in 1928. Its mandate was to sell the production of Astexco and member mills to the United States, as the first of many export markets (Perrault 1985). The Great Depression forced Seaboard into hibernation shortly after its birth. However, the competition between Seaboard, resurrected in 1935, and H.R. MacMillan provided major impetus that helped establish $\mathrm{BC}$ as a major player in the global market for forest products.

\section{The Struggle to Develop and Diversify Markets: 1930-1939}

The Great Depression led to a collapse of the existing markets for BC wood products. The U.S.S.R. started to dump wood on the world market to obtain hard currency and, bowing to depression-driven political and economic pressures, the United States first levied a duty of $\$ 1 / \mathrm{MBF}$ (thousand board feet) in 1930 , then added an excise tax of an additional $\$ 3 / \mathrm{MBF}$ in 1932 on Canadian lumber (when it was selling for $\$ 10-12 / \mathrm{MBF}$ ). Sporadic attempts by some of the U.S. industry to erect trade barriers against Canadian wood products continued throughout the rest of the century. The U.S. wood products industry has traditionally focused on protecting its home market, where domestic demand is higher than production, rather than expanding its export markets ${ }^{1}$. By 1934, the volume shipped to the U.S. from British Columbia decreased to less than $17 \%$ of the 1929 levels (BCLMA 1931-1940).

Some results of the collapse of the U.S. market and the Great Depression were: (1) the restructuring of the BC wood products industry with a shakeout of poorly financed and/or inefficient facilities, (2) the focusing on new market develop-

\footnotetext{
'This attitude may be undergoing a change with the increased focus on exports of value-added products to Japan and Europe during the latter half of the 1980s.
}

ment including Australia (where BC eventually supplied $90 \%$ of lumber imports), the U.K., China and Japan - markets that had been abandoned during the 1920s for the more lucrative U.S. market, and (3) the promotion of preferential trading policies for Commonwealth countries trading with the U.K. and among themselves (e.g. South Africa, Australia and New Zealand).

Many of the marketing and promotional tactics undertaken by the $\mathrm{BC}$ industry in the thirties are similar to those both in place and being proposed today for British Columbia, Eastern Canada, Southern U.S. and the Pacific Northwest. The Trade Extension Bureau was formed in 1930 to increase trade of BC wood products. It was composed of lumber, shake and shingle manufacturers, the provincial government and wood exporters.

In 1932, trade missions from the BC wood industry to China and the U.K. found customers who would pay more for 13 foot lengths than 26 foot lengths (MacKay 1982). By finding out what the customer wanted, the industry was able to obtain a premium for a product that was less expensive to produce (in marketing jargon this would be called "product innovation resulting from market pull").

The Trade Extension Bureau tried to rationalize standards by promoting the acceptance of scant lumber sizes in the United Kingdom. Canada and the U.S. had accepted the use of scant sizes, which were .25 inches smaller but had less variation after passing through sizing machines. British buyers felt they were being cheated since they received less wood. A $\mathrm{BC}$ trade delegation successfully explained and promoted scant sizes in the U.K. which led to a change in British standards to allow their use. This promotion and rationalization of international standards resulted in substantial transportation cost savings due to increased volume per ship and less weight per unit volume (BCLMA 1931-40). Today, both U.S. and Canadian industry and governments are wielding considerable effort to ensure that Japanese and European standards correspond to North American standards (Anon. 1989; ISTC 1989).

As the industry regained its financial health, once again Astexco mill members felt that excess profits were accruing to the MacMillan Export Company Limited which they supplied with $75 \%$ of the lumber it exported (Perrault 1985). In 1935, Seaboard was resurrected to market this lumber themselves. The forward vertical integration of Astexco mills into export sales forced H.R. MacMillan to integrate backwards by purchasing timber rights and processing facilities (MacKay 1982). The competition between Seaboard and MacMillan contributed to the healthy development and expansion of global trade for $\mathrm{BC}$ wood products. By 1938, MacMillan and Seaboard each exported over one third of all BC lumber exports (Perrault 1985). As each group attempted to gain comparative advantage in the global market, the rapid development and adoption of more efficient manufacturing techniques became a key competitive weapon. Intense local rivalries, exemplified by the Seaboard-MacMillan situation, are considered by Porter (1990) to be a critical stimulus for a nation's industry to develop a global competitive advantage.

During the 1930s, the BCLMA, an association that represented BC coastal sawmill owners including members of Astexco, was spending over half its budget to marketing $\mathrm{BC}$ wood products. Its Canadian Market Committee (devoted to increasing the use of $\mathrm{BC}$ lumber in Canada) and the Trade Extension Committee (devoted to increasing exports of $\mathrm{BC}$ lumber) 
worked in cooperation with the Trade Extension Bureau. Their main focus was to bring the customer and the producer together. The BCLMA undertook a variety of activities during the 1930s. They provided information to their member mills concerning global prices, ship subsidies, tariff restrictions, and market opportunities. In cooperation with government agencies, they established permanent trade extension offices in the U.K., South Africa, and Australia, and dispatched a trade mission to the West Indies. During a decade of increasing trade restrictions, they lobbied to erect and maintain barriers favourable to their industry. For example, they successfully lobbied for "favoured trade status" from Belgium, which resulted in a $25 \%$ increase in lumber exports to that country. Lobbying efforts in the U.K. focused on retaining the tariff preference for Commonwealth lumber (BCLMA 1931-40).

Promotional efforts concentrated on developing new markets and expanding wood use in existing markets (in marketing jargon, "market development and market penetration"). Examples of promotional efforts included developing a model home display in Australia, exhibiting BC wood samples in Palestine to introduce these species to Middle East importers, and displaying a full range of grades for all species at an exhibition in Vancouver. Of particular concern to the BC industry was the replacement of lumber exports to Japan with $\log$ exports. It is interesting to note that concern over Japan's desire to import raw materials instead of finished or semi-finished goods was of critical concern to Japan's trading partners more than fifty years ago and remains so to this day (BCLMA 1931-40; Anon. 1989). International marketing efforts were one of the factors that enabled the B.C. lumber industry to recover relatively quickly from the Great Depression.

\section{A World in Chaos: World War II}

World War II had a tremendous impact on the BC wood products industry. It provided major impetus to the plywood industry in Canada and the United States since plywood, a relatively new product, was a key component in the manufacture of airplanes (Taylor 1975). The United Kingdom wanted as much lumber as BC could export; however, cargo ships were extremely difficult to procure. This lack of shipping vessels was the impetus for Seaboard to develop their first long-term cargo charters (Perrault 1985). The war status led to more cooperation among BC lumber mills, Seaboard and H.R. MacMillan. During the war years, the U.K. received $45 \%$ of BC lumber production while the U.S. received 25\% (Perrault 1985).

The impact of World War II extended beyond the actual war years; the post-war building boom in the U.K. resulted in large two-year contracts when shipping was once again available (MacKay 1982). The building boom in the United States resulted in U.S. firms being unable to meet domestic demand for lumber and expressing little interest in export markets. During and immediately following the war, marketing had little place in the wood products industry since lumber and plywood were both considered strategic materials and demand far surpassed supply.

\section{A Period of Stability: 1950-1970}

The rebuilding to Europe and a growing world economy from 1950 to 1970 contributed to an era of stability for the BC wood products industry. However, increased competition from the solid wood industries in Sweden, Finland and the U.S.S.R. in the early 1950s prompted a reawakening of marketing efforts by the BCLMA in cooperation with both levels of government. The Canadian Wood Development Council, a national organization established to develop domestic markets for Canadian wood products, frequently worked in consort with the BCLMA, which was trying to create a global preference for B.C. coastal species and lumber products (BCLMA 1951-60).

From 1950 to 1954 , promotional efforts successfully increased the use of construction-grade lumber in residential buildings in North America through the promotion of platform frame construction techniques. To fend off the intense marketing efforts by substitute products (primarily steel, concrete and aluminum), the BCLMA built ten demonstration houses across Canada (BCLMA 1951-60).

Marketing of wood houses was not restricted to North America. The BCLMA actively promoted wood houses using CLS (Canadian Lumber Standard) materials in several markets.Ten demonstration houses, promoted by an intense publicity campaign in 1957, contributed to increasing consumer interest in the U.K. for houses built from BC wood products. However, British financial institutions were hesitant to provide mortgage financing for wood houses. In 1959, a lecture tour in the United Kingdom was arranged by the BCLMA for a Canadian mortgage authority with an international reputation. Providing this technical information to support personnel opened the U.K. market for wood housing. This is an excellent example that creating consumer demand often is insufficient for increasing sales in some markets.

Market promotion and development aided the $\mathrm{BC}$ industry in benefiting from the growing world economy, providing export demand for lumber that exceeded supplies available from coastal operations during the 1950 s. This supplied the impetus for the wood products manufacturing industry to expand beyond the coastal region and Vancouver Island into the less accessible interior regions of British Columbia. While the BCLMA represented the coast industry, each developing region in the $\mathrm{BC}$ interior created its own association. These included the Cariboo Lumber Manufacturers Association (CLMA), the Northern Interior Lumber Association (NILA) and the Interior Lumber Manufacturers Association (ILMA). Lumber was no longer the only solid wood product from $\mathrm{BC}$ and each manufacturing sector formed its own association, for example, the Plywood Manufacturers Association of BC, the Consolidated Red Cedar Shingle Association and the Canadian Pulp and Paper Association (BC Division). The proliferation of industry associations resulted in redundant and underfinanced export-oriented promotional campaigns and the duplication of operational expenditures. In 1960, all of these associations (except the NILA) banded together to form the Council of Forest Industries of British Columbia (COFI) to coordinate activities and address concerns that affected the British Columbia industry as a whole. In 1966 , these and other similar organizations ceased to exist as separate entities and amalgamated into a single organization, $\mathrm{COFI}$, to rationalize operations and get best value from each dollar spent.

Thus, the fragmentation and divisiveness that resulted from new operating regions and products eventually resulted in a cohesive and strong international voice for the $\mathrm{BC}$ forest industry. Permanent field offices that had been established under the BCLMA were continued under COFI. These included offices in London (established in 1954), Australia (1961), Holland (1962) 
and France (1966). A trade mission to Western Europe and the Far East in 1966 was one of the first ventures of the newly amalgamated COFI. The coordination of both incoming and outgoing trade missions has continued to be an important component of COFI programs.

The U.S. tariff on Canadian wood products, initiated in 1932, had been removed with the start of World War II. However, in 1962, the U.S. industry, primarily focused on domestic markets, once again requested tariff restrictions on Canadian lumber which had been capturing increasing U.S. market share. COFI, representing a unified BC lumber industry, was instrumental in defeating this movement both as a participant in Trade Commission hearings and in the political arena. The quest for trade barriers on Canadian wood products has been a recurring objective of some U.S. producers. Different forms of forest land ownership, tenure and government, along with a maturing market for softwood lumber, are fundamental factors that provoke attempts by U.S. firms to either maintain their domestic market share or increase price levels for their own products (Irland 1987).

During the sixties, technical research became an important component of the marketing and promotional efforts of the forest products industry in British Columbia and throughout North America. As technologies, such as kiln drying and machine stress rating were developed, so was the need for technical research on the impact of these technologies on wood properties. Research on machine stress rated lumber in the $1960 \mathrm{~s}$ led to an intense European promotional effort in the early seventies. The focus and importance of technical research, as a key component of marketing strategy, continues to this day, as exemplified by both the in-grade testing program and COFI's technical involvement with the development of unified codes for the economic union of 12 European countries. A single product standard and building code will be established in 1992 in what will become the world's largest single market. COFI personnel have been designated as the official Canadian industry spokespeople on all technical wood product issues to protect and expand the Canadian share of this important export market (ISTC 1989).

\section{A Decade of Expansion: 1970-1979}

During the seventies, lumber production in British Columbia increased dramatically with the increased utilization of wood from the BC interior. To maintain markets for this expansion, market development and promotion became a continuous, strategic and long-term effort, not just tactical and short-term. The first Cooperative Overseas Market Development Program (COMDP) was initiated in 1971 and continues today. COMDP is equally financed by the Federal government, the Provincial government, and COFI. It has been widely imitated both in the United States and other countries.

Continuous market development and product promotion campaigns during the seventies helped provide markets for the ever increasing supply of lumber and plywood from British Columbia. By 1974 there were trade offices in the U.K., France, West Germany, the Netherlands, Belgium, Italy, Australia and Japan to promote the use of BC wood products. Japan received particular attention (COFI 1971-80).

Japan was a key target market for the BC solid wood industry. In 1973, COFI hosted 25 missions and groups from Japan who were interested in $\mathrm{BC}$ wood products. The COMDP built wood demonstration homes in Japan in 1974 to promote the use of BC woods, and a second full-time staff member was hired to work in Japan. Additional efforts by U.S. organizations such as the Western Wood Products Association and the American Plywood Association combined with BC efforts to successfully convince the Japanese to accept the use of both NLGA lumber and platform frame construction techniques. Efforts included promotion (e.g. a 1975 film in Japanese on how to construct a platform frame house out of $\mathrm{BC}$ wood products) and technical support (e.g. in 1978 the Japanese Agricultural Standards (\#600) were adjusted to coincide with the National Lumber Grades Authority regulations). This resulted in the rationalization of North American and Japanese lumber grades (COFI 1971-80). Similar lumber grading standards led to almost 10,000 Japanese housing starts in 1978 that used the 2 by 4 inch platform frame construction method (Hardy 1985). Residential building using this type of construction in Japan has increased steadily, with over 48,000 starts in 1990 (Anonymous 1989).

While much attention was paid to Japan, other markets were not ignored. Technical work contributed to the acceptance by the Danish Building Authority of COFI-graded plywood. Market development within Canada also progressed, with intensive technical and promotional efforts increasing the use of permanent wood foundations (promoted by the Canadian Wood Council) to 10,000 houses in Canada by 1978 .

The tremendous growth in the production of forest products in British Columbia coincided with a substantial building boom that occurred in the United States. Canada's reliance on this market increased dramatically, and for most of the decade over $50 \%$ of BC lumber was shipped to the United States. Marketing efforts in the U.S. focused on educating perspective buyers on the interior species mix of Spruce-Pine-Fir (SPF). Exports to other foreign markets continued but were dwarfed by U.S. demand (Table 1). Lumber production in the U.S. could not keep up with growing demand creating market opportunities for BC lumber. The seventies and eighties were also decades of explosive growth in pulp and paper capacity in the province.

\section{Bust and Boom: 1980-1990}

The eighties started with a recession that many experts thought the industry could avoid due to previous market diversification efforts. However, once the recession expanded from a North American phenomenon to global occurrence, there was no escape. Downsizing, layoffs and liquidations in the early part of the decade were followed by expansion, modernization and automation during the recovery in the second half. Marketing efforts, while curtailed, continued throughout the recession years and helped to establish British Columbia as a secure source of supply. Once again, the U.S. industry petitioned for trade restrictions against Canadian lumber products. After regulatory efforts initially failed in 1983, the U.S. industry convinced their government to seriously consider a $30 \%$ tariff on Canadian lumber a few years later. Bilateral negotiations led to the 1986 Memorandum of Understanding (MOU) between Canada and the United States which placed a 15\% lumber export tax on Canadian lumber. This tax was quickly replaced by increased stumpage rates in British Columbia and led to a renewed impetus for exploring and developing additional overseas markets.

However, other countries were discovering the attractiveness of the global market. Southern yellow pine from the 


\begin{tabular}{|c|c|c|c|c|c|c|c|c|}
\hline Year & 1929 & 1936 & 1946 & 1950 & 1960 & 1970 & 1980 & 1990 \\
\hline \multicolumn{9}{|l|}{ Shipments in (billion } \\
\hline B.F.) & $(2.0)$ & (1.8) & (1.7) & $(2.6)^{2}$ & $(2.8)^{3}$ & $(3.8)^{4}$ & (11.7) & (14.0) \\
\hline Canada & 52.4 & 30.4 & 45.3 & 31.3 & 24.2 & 17.0 & 21.4 & 23.2 \\
\hline U.S.A. & 27.4 & 10.6 & 11.3 & 49.0 & 42.0 & 41.8 & 54.0 & 53.0 \\
\hline Mid-East & 0.2 & 0.5 & 1.1 & 0.3 & 0.0 & 0.0 & 0.5 & 0.0 \\
\hline Africa & 0.8 & 3.5 & 5.6 & 3.4 & 5.1 & 1.5 & 1.3 & 0.0 \\
\hline Asia & 12.2 & 8.4 & 0.0 & 0.0 & 0.1 & 13.9 & 9.3 & 12.3 \\
\hline Europe & 0.0 & 0.5 & 2.0 & 0.5 & 1.6 & 5.0 & 4.5 & 3.1 \\
\hline U.K. & 3.5 & 37.7 & 24.5 & 9.4 & 18.4 & 10.5 & 4.1 & 5.3 \\
\hline S. America & 0.2 & 0.5 & 0.7 & 0.1 & 0.1 & 0.0 & 0.1 & 0.0 \\
\hline Australia \& New Zealand & 2.5 & 7.4 & 4.3 & 3.8 & 4.3 & 3.4 & 1.1 & 1.0 \\
\hline Other Exports & 0.8 & 0.6 & 5.2 & 2.2 & 4.4 & 6.9 & 1.0 & 1.8 \\
\hline
\end{tabular}

${ }^{1}$ Until 1972 shipments are from Coast mill production only.

${ }^{2}$ Total Coast and Interior Lumber Production for $1950=3.4$ billion B.F

${ }^{3}$ Total Coast and Interior Lumber Production for $1960=5.3$ billion B.F.

${ }^{4}$ Total Coast and Interior Lumber Production for $1970=7.7$ billion B.F.

Source: BCLMA and COFI Annual Reports 1936-1991.

southeastern United States started competing with $\mathrm{BC}$ white woods in Europe. Washington and Oregon, in cooperation with the U.S. Federal government, were spending large sums to develop markets for U.S. wood products in Japan using many of the same techniques BC had pioneered since 1930. Chile and New Zealand were starting to harvest Radiata Pine plantations which were approaching maturity. The global competitive environment for forest products was becoming more complex, aggressive and riskier, with new competitors, increasingly complex methods of trade barriers and tariffs, and new trading alliances. Intensive marketing programs have been put in place to help maintain BC's historic position as a world leader in the global trade of forest products.

The British Columbia forest products industry, in cooperation with both levels of government, is reacting to BC's increased competitive difficulties with commodity wood products in the global market by maintaining market development efforts and increasing product diversification programmes. In 1989, the Co-operative Industrial and Market Development Program (CIMDP) was formed. Financed in the same manner as the COMDP, its purpose is to assist the growth of secondary manufacture of wood products in British Columbia. The strategies of the CIMDP are: (1) to develop new market and product opportunities for B.C. specialites, (2) to promote specialty products globally, (3) to provide technical services, and (4) to generate incoming inquiries. Generally, its functions are similar to those of COFI, with whom they co-operate, but for wood specialty products.

\section{Conclusions - The Past, The Present and The Future}

Historical occurrences can illuminate effective marketing efforts for the present and the future. Marketing alone can neither create nor maintain a healthy lumber industry; however, without marketing efforts it would be extremely difficult for regional lumber industries to evolve from basic commodity production to value-added manufacturing. While history cannot provide a blueprint for the future, it can help the regional lumber industries become better prepared for future global competition.

One of the key lessons is the success of cooperation on two distinct levels. The first level is cooperation among forest product companies through industry associations. Past and current successes of organizations such as the Canadian Wood Council and the Council of Forest Industries of British Columbia indicate a strong need for future teamwork and collaboration among companies. This cooperation must not dilute the interfirm rivalries, exemplified by the MacMillan-Seaboard competition, nor decrease internal competition for resources, manpower, and markets. Intra-industry cooperation can create both economies of scale in marketing and promotion and help develop a single "face" for the industry in foreign markets. The second level is the cooperation between different levels of government and industry within the confines of fair trade policies. Past and continuing successes of programs such as COMDP ${ }^{2}$ signify the need to continue such cooperative efforts. Care must be taken not to allow government involvement to diminish the competitiveness within a regional lumber industry (for an excellent discussion of the role of government, see Porter (1990), pages 86-89).

Throughout the history of the marketing of BC lumber products, overreliance on a single market has created financial woes for the industry during subsequent economic downturns. History has demonstrated the need to diversify markets through product, process and marketing innovation. The BC lumber industry had to react quickly to a prohibitively high U.S. tariff in the early thirties by expanding sales through preferential trade agreements among Commonwealth countries. Expanding sales in the U.S. market quickly compensated for the loss of the Japanese market in the late 1930s and early 1940s.

Maintaining an awareness of shifting global trends and reacting quickly and decisively has been and will remain an essential characteristic of a regional lumber wood products industry interested in exporting its products. For example, threats from substitute materials in the fifties resulted in an intense program to promote increasing the use of wood products in residential construction. Increasing world competition in commodity wood products in the eighties led to intensive efforts to shift production from commodities to specialty products.

\footnotetext{
${ }^{2}$ In the United States the funding of the Center for International Trade in Forest Products (CINTRAFOR) at the University of Washington is an example of joint industry-government cooperation.
} 


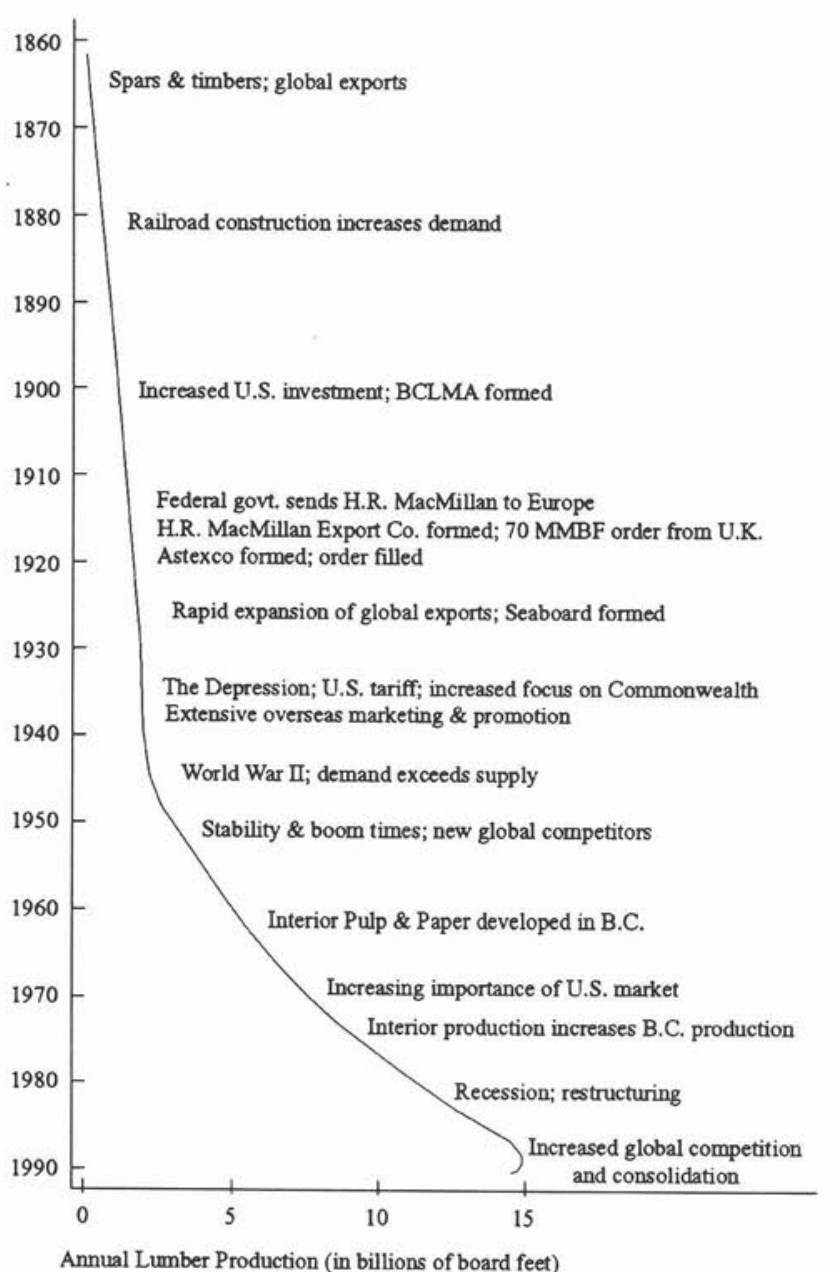

Figure 1. Summary of key historical events and lumber production in $\mathrm{BC}$.

There are other lessons to be learned about competitors and markets from this examination of the history of $\mathrm{BC}$ marketing efforts for softwood lumber. Since the early 1920s, British Columbia has relied heavily on foreign markets to sell the constantly increasing production of solid wood products (Table 1). There is a propensity for importing countries with domestic lumber industries to restrict access of imported lumber to protect their own industry base (e.g., U.S. trade restrictions on Canadian lumber). Only constant vigilance, the maintenance of fair trading policies, and effective political efforts to maintain free and open trade can open the channels necessary for a lumber industry that relies on exporting its products. In the specific case of British Columbia, the geographical proximity, market size, and net deficit of solid wood products ensure that the United States will always be an important market for lumber exports. However, efforts to continue to develop alternative export markets must be maintained to ensure market breadth and minimize the industry's vulnerability to the actions of a single country.

As exemplified by changing Japanese imports in the early 1930s, many importing countries maintain a preference for raw materials for remanufacture in their own country rather than importing finished goods. The industry must continue its efforts to encourage importing countries to minimize both tariff and non-tariff restrictions of more finished wood products. This includes continued efforts to rationalize international codes and standards. Technical research and promotion, com- bined with political efforts, can help create codes and standards which will not act as non-tariff trade barriers.

A review of the past cannot guarantee success in future, but it can provide insight into the marketing strategies which can contribute to a successful regional lumber industry. This historical account does not propose more of the same specific tactics but rather shows attitudes and efforts that built past achievements and failures. It points to marketing efforts that have helped the largest exporting lumber region in the world (British Columbia), grow and prosper during the first nine decades of this century (Figure 1). The lessons to be learned can help other regional wood products industries prosper will into the next century.

\section{Acknowledgement}

The author would like to thank Ainsworth Lumber Company, Forintek Canada Corporation, FEPA (Forest Economics and Policy Analysis and Research Unit), and Forestry Canada for their support.

\section{References}

Anonymous. 1989. The Japanese Solid Wood Products Market: Profile and Outlook. Prepared by the Office of Forest Products and Domestic Construction, Basic Industries Sector, U.S. Department of Commerce. April, 1989. 21 p.

British Columbia Lumber Manufacturers Association. Annual Reports. 1926-1930. Council of Forest Industries of BC Library, Vancouver, B.C.

BCLMA Annual Reports. 1931-1940. Council of Forest Industries Library, Vancouver, BC.

BCLMA Annual Reports. 1951-1960. Council of Forest Industries Library, Vancouver, BC.

COFI (Council of Forest Industries of British Columbia) Annual Reports. 1971-1980. Council of Forest Industries Library, Vancouver, BC.

COFI. 1990. Fact Book 1990. Vancouver, BC.

Forestry Canada. 1990. Forestry Facts. Minister of Supply and Services Canada, Cat. No. Fol-4/1990, Ottawa, ON.

Hardie, M. 1985. Timber Frame Promotion Strategy: Preliminary Report, May, 1985. Discussion Paper. Council of Forest Industries Library, Vancouver, BC.

Irland, L.C. 1987. Canada - U.S. Forest Products Trade: Tensions in a Maturing Market. Forest Products Journal 37(2): 21-29.

ISTC (Industry, Science and Technology Canada). 1989. B.C. and Europe 1992. In British Columbia Industrial Development Bulletin, Special Issue, December 1, 1989. 8 p.

Lean, G. 1991. Canadian Chainsaw Massacre. The London Observer, December 1, 1991. p. 16-21.

MacKay, D. 1982. Empire of Wood: The MacMillan Bloedel Story. Douglas \& McIntyre, Toronto/Vancouver.

Perrault, E.G. 1985. Wood \& Water: The Story of SEABOARD Lumber and Shipping. Douglas \& McIntyre, Toronto/Vancouver.

Porter, M.E. 1980. Competitive Strategy: Techniques for Analyzing Industries and Competitors. The Free Press, New York.

Porter, M.E. 1990. The Competitive Advantage of Nations. Harvard Business Review. (March-April): 73-93.

Taylor, G.W. 1975. Timber: History of the Forest Industry in B.C. J.J. Douglas Ltd., Vancouver.

Woodbridge Reed \& Associates. 1988. "Canada's Forest Industry: The Next Twenty Years: Prospects and Priorities" Prepared for the Canadian Forestry Service, Industry, Trade and Technology Directorate, Economics Branch, Ottawa. Volume 1, Strategic Analysis. 